\title{
Mídia e imagem pública do parlamento
}

DOI: $10.1590 / 1809-58442015116$

\section{Antonio Teixeira de Barros}

(Universidade de Brasília, Centro de Ciências Humanas e Sociais, Faculdade de Sociologia, Programa de Mestrado em Ciência Política.

Câmara dos Deputados,

Centro de Formação. Brasília - DF, Brasil)

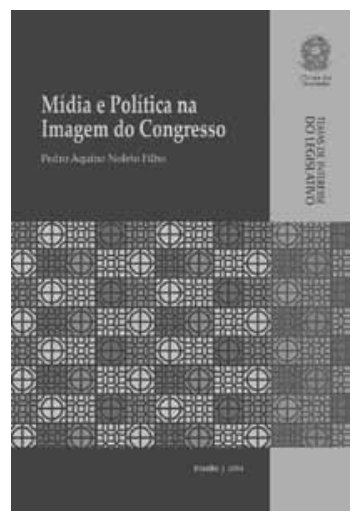

NOLETO FILHO, P. A. Mídia e política na imagem do Congresso. Brasília: Edições Câmara, 2014. 340 p. Versão eletrônica disponível em: http://bd.camara.gov.br/bd/bitstream/ handle/bdcamara/18759/midia_politica_noleto.pdf? sequence $=1$

publicação Mídia e política na imagem do Congresso resulta
de pesquisa empírica para tese de doutoramento em
Comunicação, na Universidade de Brasília, em 2009, de Noleto Filho. O trabalho teve como eixo analítico o estudo sobre as funções da Mídia na construção da imagem pública do Legislativo federal e suas implicações para a democracia. Alguns aspectos devem ser ressaltados como a densidade teórica, fruto da convergência entre três áreas: estudos de Mídia e Política, contribuições da Ciência Política, e da Sociologia Política. Igualmente relevante, foi a combinação de pesquisa extensiva com pesquisa intensiva. A amplitude empírica (típica da primeira) foi aproveitada para conferir maior densidade, em uma abordagem compreensiva, na qual "busca-se compreender os porquês da imagem pública cronicamente negativa do Congresso Nacional” (p.15). 
O objetivo da obra é analisar as principais causas da imagem pública negativa do Congresso Nacional e como a Mídia atua no processo de construção social da realidade político-parlamentar. Como adverte o autor, não se pretende advogar em prol de uma visão conspiratória da Mídia em relação ao mundo da política. "Almeja-se adotar uma noção ponderada entre a crítica radical e os dogmas liberais. Isto é, a mídia não corrói intencionalmente a legitimidade do Congresso, mas tampouco exerce apenas o papel de um mediador isento" (p.15). Em suma, o livro analisa a imagem pública cronicamente negativa do Congresso Nacional, a partir de uma triangulação: o exame de fatores político-institucionais, de características da cultura política e das práticas jornalísticas. Esse é o tripé para a construção social da realidade política brasileira. Há uma nítida convergência, portanto, entre os enfoques sociomediáticos e os enquadramentos da Ciência Política.

Para fins de síntese, é oportuno citar como as questões centrais da pesquisa são ressaltadas pelo prefácio, assinado pelo orientador da tese, o professor Luís Felipe Miguel, do Instituto de Ciência Política da UnB e um dos expoentes da área de Mídia: "É inegável que a mídia desempenha um papel na produção dessa imagem negativa, mas que papel é esse?" (p.9).

Outro aspecto metodológico que deve ser realçado diz respeito à captação e sistematização das percepções dos próprios parlamentares sobre o que a imprensa publica acerca do palco e dos bastidores do Congresso Nacional, visto como uma grande arena multiator. Com uma perspectiva próxima da observação etnográfica, o autor entrevistou 20\% dos parlamentares que atuavam na Legislatura 2003-2007, o que corresponde a 102 deputados (de um total de 513). Uma amostragem que excede os patamares qualitativos convencionais. $\mathrm{O}$ propósito foi o de realizar uma espécie de estudo de recepção com os parlamentares, a fim de compreender como eles próprios decodificam os conteúdos e as representações da política mediatizada.

A análise mostra que os entrevistados convergem em uma percepção de que os conteúdos publicados não condizem com o que de fato ocorre na arena legislativa. Para os informantes, 
a imagem pública da Câmara "seria uma imagem distorcida, por enfatizar os fatos negativos e não refletir adequadamente os acontecimentos que se dão no âmbito parlamentar" (p. 193). Ao serem indagados se a imagem da Câmara na Mídia corresponde à realidade, 55,2\% responderam que não; 28,9\% concordaram parcialmente; e $15,9 \%$ concordaram inteiramente.

Além das percepções dos parlamentares, o estudo considera ainda os valores e práticas da cultura jornalística. $\mathrm{O}$ argumento é baseado na hipótese do "negativismo midiático", isto é, a noção de que a Mídia produz representações negativas não só da política, mas dos demais campos sociais. Isso é explicado pelo habitus jornalístico, que privilegia acontecimentos imprevistos, trágicos, inusitados, que envolvem conflitos e desvios. São esses enquadramentos que figuram no topo da escala de valor-notícia.

Os méritos relacionados à construção textual e ao desenho da pesquisa certamente se justificam pelo lugar de fala do autor, ao articular experiências acadêmicas e profissionais. Noleto Filho atuou como jornalista em veículos privados e informativos da Câmara, além de ocupar cargos de chefia e direção no sistema informacional da instituição. Também atua há mais de cinco anos como pesquisador do Programa de Pós-Gradução do Centro de Formação da Câmara, na linha de pesquisa sobre Comunicação e democracia.

As conclusões do autor estão em sintonia com argumentos do mainstream dos debates sobre a natureza e as características do parlamento. Esses estudos, desde o célebre texto de Max Weber sobre as ambiguidades da função mediadora do parlamento (um capítulo de Economia e Sociedade), ressaltam as consequências de sua configuração de arena, a lógica de política de disputa interna, a representação de interesses diversos, o aumento do nível de visão crítica dos representados e a contínua disputa pelo controle da visibilidade entre os atores políticos (e entre eles e a imprensa).

Por fim, cabe ressaltar que o estudo em apreciação é uma demonstração de como a área de Mídia e Política, apesar de recente, está em expansão, rumo a uma nova subespecialização: Mídia e parlamento. Isso implica o realce de novas problemáticas 
de pesquisa a serem investigadas, metodologias empíricas mais específicas e abordagens que superem uma visão generalista de "Mídia e Política".

Antonio Teixeira de Barros (autor da resenha)

Doutor em Sociologia e Mestre em Comunicação. Docente e pesquisador do Programa de Mestrado em Ciência Política da Universidade de Brasília e do Centro de Formação da Câmara dos Deputados (Cefor), Brasília-DF. E-mail: antonibarros@gmail.com 